TECHNICAL PAPER

\title{
Physical-Chemical Evaluation of Hydraulic Fracturing Chemicals in the Context of Produced Water Treatment
}

\author{
by \\ Mary Kay Camarillo $^{\mathrm{a}^{*}}$, Jeremy K. Domen ${ }^{\mathrm{a}}$, William T. Stringfellow ${ }^{\mathrm{a}, \mathrm{b}}$, \\ ${ }^{a}$ Ecological Engineering Research Program, School of Engineering \& Computer Science, \\ University of the Pacific, 3601 Pacific Avenue, Stockton, CA 95211, USA. \\ ${ }^{\mathrm{b}}$ Earth \& Environmental Sciences Area, Lawrence Berkeley National Laboratory, \\ 1 Cyclotron Road, Berkeley, CA 94720, USA. \\ *Corresponding author. Email: mcamarillo@ pacific.edu Phone: +1-209-946-3056; FAX: \\ +1-209-946-3086.
}

Revised for submission to:

Journal of Environmental Management

August 2016

Page 1 of 34

(C) 2016. This manuscript version is made available under the Elsevier user license http://www.elsevier.com/open-access/userlicense/1.0/ 


\begin{abstract}
Produced water is a significant waste stream that can be treated and reused; however, the removal of production chemicals — such as those added in hydraulic fracturing - must be addressed. One motivation for treating and reusing produced water is that current disposal methods - typically consisting of deep well injection and percolation in infiltration pits-are being limited. Furthermore, oil/gas production often occurs in arid regions where there is demand for new water sources. In this paper, hydraulic fracturing chemical additive data from California are used as a case study where physical-chemical and biodegradation data are summarized and used to screen for appropriate produced water treatment technologies. The data indicate that hydraulic fracturing chemicals are largely treatable; however, data are missing for 24 of the 193 chemical additives identified. More than one-third of organic chemicals have data indicating biodegradability, suggesting biological treatment would be effective. Adsorptionbased methods and partitioning of chemicals into oil for subsequent separation is expected to be effective for approximately one-third of chemicals. Volatilization-based treatment methods (e.g. air stripping) will only be effective for approximately $10 \%$ of chemicals. Reverse osmosis is a good catch-all with over $70 \%$ of organic chemicals expected to be removed efficiently. Other technologies such as electrocoagulation and advanced oxidation are promising but lack demonstration. Chemicals of most concern due to prevalence, toxicity, and lack of data include propargyl alcohol, 2-mercaptoethyl alcohol, tetrakis hydroxymethyl-phosphonium sulfate, thioglycolic acid, 2-bromo-3-nitrilopropionamide, formaldehyde polymers, polymers of acrylic acid, quaternary ammonium compounds, and surfactants (e.g. ethoxylated alcohols). Future studies should examine the fate of hydraulic fracturing chemicals in produced water treatment
\end{abstract}


trains to demonstrate removal and clarify interactions between upstream and downstream processes.

\section{Key Words}

Hydraulic fracturing; Oil and gas production; Produced water; Wastewater treatment 


\section{Introduction}

During the extraction of oil and gas $(\mathrm{O} \& \mathrm{G})$ from geological reservoirs, water is also extracted, often in quantities that far exceed the volumes of O\&G produced (Clark and Veil, 2009; Veil, 2015). Water is the O\&G industry's largest volume waste stream and the volume of water produced is expected to rise from current estimated levels of approximately 13 billion gallons per day to more than 15 billion gallons per day by 2017 (BCC Research LLC, 2012). The United States alone generates approximately one trillion gallons of produced water per year (Veil, 2015). Produced water volumes tend to increase dramatically as mature fields pass peak production levels and for crude wells nearing the end of their productive existence; water production can exceed oil production by more than ten times (BCC Research LLC, 2012; Clark and Veil, 2009; Veil, 2015).

Produced water is often reused on-field for purposes such as maintaining reservoir pressure, water flooding, cyclic steam injection, and other secondary and tertiary production processes (Clark and Veil, 2009; Veil, 2015). Other beneficial uses for produced water include power plant cooling fluid, dust and ice control, and irrigated agriculture, particularly where the salt content of the produced water is naturally low (Clark and Veil, 2009; Dallbauman and Sirivedhin, 2005; Guerra et al., 2011; Veil, 2015). However, almost 50\% of produced water is not reused and must be disposed, most commonly by well injection, but also by methods that could potentially contaminate surface waters and shallow aquifers (Clark and Veil, 2009; Veil, 2015).

In the face of continuing drought in the Western USA and the expanding recognition that water is an undervalued resource, there is growing interest in reclaiming produced water for beneficial reuse, particularly in arid areas where agriculture and $O \& G$ production coincide 
geographically. O\&G production activities are under increasing regulatory scrutiny and there is mounting pressure for the industry to change water management practices and lessen potential environmental impacts from inadequately treated wastewaters. In order for produced water to be diverted to beneficial reuse in agriculture, it is important to insure that adequate safeguards are in place.

The increased regulation and public scrutiny surrounding unconventional O\&G production activities, particularly hydraulic fracturing, is an important aspect of produced water beneficial reuse. Recent studies have shown that a wide array of anthropogenic chemicals are used in O\&G fields and that these chemicals and their degradations products can occur in produced water (Ferrer and Thurman, 2015a, b; Lester et al., 2015; Stringfellow et al., 2014). Since typical produced water treatment trains are designed for the separation and recovery of gaseous or hydrophobic hydrocarbons, the question rises whether commonly used treatment systems will remove hydraulic fracturing chemicals and other O\&G field chemicals (M-I SWACO, 2012; Shaffer et al., 2013).

The amount of treatment produced water receives varies. Minimally, produced water is treated using gravity settling (e.g. oil-water separation) to recover oil product, separate gas, and remove particulate matter (Arthur et al., 2005; Fakhru'l-Razi et al., 2009). Additional treatment may consist of dissolved air/gas flotation or coagulation-flocculation (Arthur et al., 2005). Nut shell filters are used as coalescing media to remove residual oil (Liu and Liu, 2016; Srinivasan and Viraraghavan, 2008). Water softening is often used to reduce scale-forming minerals that are problematic in enhanced oil recovery and disposal (Fakhru'l-Razi et al., 2009). The most advanced systems use multimedia filtration (anthracite, sand, and garnet), ion exchange softening (weak acid cation softening), and cartridge filtration followed by a two-pass RO system (Liske 
and Leong, 2006; Orr, 2011). Although some degree of trace contaminant removal likely occurs in even the most basic treatment processes via capture onto particle surfaces and into small oil droplets (Faksness et al., 2004), produced water treatment systems have not been designed to remove hydraulic fracturing chemicals specifically.

The use of hydraulic fracturing in $\mathrm{O} \& \mathrm{G}$ production contributes organic content, toxicity, and salinity that can interfere with produced water treatment (Abualfaraj et al., 2014; Barbot et al., 2013; Chapman et al., 2012; Haluszczak et al., 2013; Thacker et al., 2015). The presence of salinity, trace toxins, and recalcitrant organics present unique challenges that require a comprehensive treatment strategy (Gregory and Mohan, 2015; Shaffer et al., 2013). Produced waters from fractured wells contain high oxygen demand (Lester et al., 2015; NYS DEC, 2011; Stringfellow et al., 2014) that can interfere with physical-chemical treatment and cause fouling in membranes (Evans et al., 2014; He et al., 2014). Produced water from fractured wells appears biodegradable (Kekacs et al., 2015; Strong et al., 2014), and treatable using biological (Lester et al., 2015) and physical-chemical treatment methods (He et al., 2014; Jiang et al., 2013; Walsh, 2013). However, verification of removal of hydraulic fracturing chemicals in produced water treatment trains is needed.

Here, we use fundamental physical and chemical properties and biodegradability test results to examine treatability of hydraulic fracturing chemicals in conventionally used and widely available treatment processes. We evaluate whether technologies and processes developed for the treatment of naturally occurring hydrocarbons and salts can remove anthropogenic chemicals. Conventional produced water is described elsewhere (Arthur et al., 2005; Clark and Veil, 2009; Colorado School of Mines, 2009; Fakhru'l-Razi et al., 2009; Igunnu and Chen, 2012). Here, we evaluate whether well-established physical, chemical, and biological 
processes can be combined into treatment trains to produce effluents suitable for disposal or beneficial uses, particularly irrigation and groundwater recharge.

\section{Methods}

A detailed description of the methods are available in the supplementary materials. Briefly, hydraulic fracturing chemical use in California has been previously characterized, and this reviewed and a vetted data set was used here as the basis for which chemicals are used and their frequency of use (Stringfellow et al., 2015). We examined the treatability of the 193 unique chemical additives identified by Chemical Abstract Service Registration Number (CASRN).

Data on chemical additive structure and molecular weight were collected using TOXNET and EPISuite software (National Library of Medicine, 2013a, b). Physical-chemical data on melting point, boiling point, flash point, vapor pressure, water solubility, octanol-water partition coefficient $\left(K_{o w}\right)$, soil organic carbon-water partitioning coefficient $\left(K_{o c}\right)$, and Henry's Law constant $\left(K_{H}\right)$ were compiled.

Organic chemicals with $\log K_{o w}>2$ were considered candidates for adsorption by activated carbon and other adsorptive media and also for removal by partitioning into the oil fraction for removal by oil-water separation (Bellona et al., 2004; Crittenden et al., 2012; U.S. EPA, 2012). Organic chemicals with $\log K_{o c}>3$ were considered candidates for adsorption onto organic media (U.S. EPA, 2012). Organic chemicals with Henry's Law constants $\left(K_{H}\right)$ of $1 \times 10^{-}$

${ }^{3} \mathrm{~atm}-\mathrm{m}^{3} \mathrm{~mol}^{-1}$ or greater $\left(\log K_{H}>-3\right)$, were considered candidates for removal by dissolved air/gas flotation (U.S. EPA, 2012; Watts, 1998). Organic chemicals were considered candidates for biological treatment based on available standardized biodegradation data (European Chemicals Agency (ECHA), 2000; National Library of Medicine, 2013c) or were shown to be biodegradable using similar protocols in published literature. Removal of chemicals by 
nanofiltration/reverse osmosis $(\mathrm{NF} / \mathrm{RO})$ was predicted using a molecular weight cut-off (MWCO) of 200-400 amu based on DOW Chemical FILMTEC NF membranes and 100 amu based on DOW Chemical FILMTEC RO membranes (Dow Chemical, 2015a, 2015b).

\section{Results}

The 193 chemical additives identified by Stringfellow et al. (2015) represent a range of functions in hydraulic fracturing. The physical-chemical properties of the additives are variable (Figures $1-4$ ), suggesting multiple treatment processes are needed for complete removal. Of the additives, 155 are organic and 38 are inorganic. Many of the additives have significant theoretical oxygen demand (Figure 5), indicating oxidizing treatments such as biological treatment are needed. Available data indicate many additives are biodegradable (Figure 6). When classified by primary function and/or chemical type (when function is not clear), potential removal in conventional produced water treatment systems is apparent based on physicalchemical properties (Table 1). Based on the results in Table 1, the most universally applicable treatment technologies are biological treatment and RO. Groups of chemicals that are most difficult to treat are acids/bases, breakers, and corrosion inhibitors (Table 1). Twenty-four of the 193 chemicals are missing physical-chemical data (Table S1) and these chemicals fall into the functional categories of corrosion inhibitors, scale control agents, surfactants, and other categories. The major categories of chemicals and their potential removal in treatment systems is described in more detail below.

\subsection{Treatability of Biocides and QACs}

Biocides used in hydraulic fracturing present a challenge for treatment due to their toxicity (Table 2). Quaternary ammonium compounds (QACs) are also a concern for the same reason although it is not always clear if QACs are being added as biocides or as surfactants 
(Table 3). At least one QAC identified — alkyl dimethyl benzyl ammonium chloride (68424-288) — is used as a biocide to control corrosion-inducing bacteria (Kahrilas et al., 2015). The most commonly used biocides in California are 2-methyl-3(2H)-isothiazolone (2682-20-4) and 5chloro-2-methyl-3(2H)-isothiazolone (26172-55-4). These two biocides are not commonly used in others parts of the U.S.; however the other biocides are commonly used throughout the U.S. (U.S. EPA, 2015a). Biocides are expected to be a major obstacle for treating produced water from stimulated wells.

Based on physical-chemical data, none of the biocides and only one of the QACs (N,NDimethyldecylamine, 1120-24-7) are candidates for removal by volatilization. None of the biocides and only three QACs [(dicoco dimethyl ammonium chloride (61789-77-3), decyldimethylamine (1120-24-7), and alkyl dimethylbenzyl ammonium chloride (68424-85-1)] are candidates for removal by adsorption or by partitioning into the oil fraction that is removed by oil-water separators.

Biological treatment is possible for many of the biocides and QACs. Isothiazolones can be treated in biological treatment systems (Jacobson and Williams, 2000; Laopaiboon et al., 2001). Biodegradability of QACs is possible under appropriate conditions (Kreuzinger et al., 2007; Tezel et al., 2012), and biological treatment has been demonstrated (Laopaiboon et al., 2002). Glutaraldehyde and formaldehyde are also biodegradable, suggesting biological treatment (Doronina et al., 1997; Laopaiboon et al., 2008; Leung, 2001). Biological treatment of 2,2dibromo-3-nitrilopropionamide (DBNPA), commonly used in hydraulic fracturing (Kahrilas et al., 2015), is possible as long as inhibition is controlled (Choi et al., 2015). Published demonstration of the biodegradability of tetrakis hydroxymethyl-phosphonium sulfate (THPS) could not be located. Five of the biocides and four of the QACs have log $K_{o c}$ high enough to 
suggest sorption onto organic particles, which further suggests removal in biological treatment systems (Sarkar et al., 2010).

Only three of the biocides have molecular weights large enough for efficient removal (>90\%) by NF. With the exception of formaldehyde (50-00-0) and ethaneperoxoic acid (79-210 ), the remaining biocides would be efficiently removed by RO. The organic nature of the biocides suggests that electrocoagulation and advanced oxidation processes might be useful; further testing is warranted.

\subsection{Treatability of Breakers}

Breakers can be organic enzymes or inorganic oxidants. In California, the most commonly used breaker is ammonium persulfate (7775-27-1), used in $85 \%$ of treatments. With the exception of hydrogen peroxide (7722-84-1), inorganic breakers are added as salts that increase the salinity of fracturing fluids. The inorganic breakers are strong oxidants that readily decay and are unlikely to be found in produced water. Organic breakers include hemicellulose enzyme (9025-56-3), which is used in $68 \%$ of treatments. None of the breakers have $\log K_{H}$ or $\log K_{o w}$ values that would suggest removal by volatilization or adsorption, although ammonium ions (originating from ammonium persulfate) can be volatilized to ammonia for removal by air stripping. Ammonium ions can also be removed by adsorption onto activated carbon media (Boopathy et al., 2013), oxidation in biological treatment systems (Tchobanoglous et al., 2013), and removal by either NF or RO (Hayrynen et al., 2009).

While physical/chemical data could not be located for the organic breakers, these chemicals are expected to be biodegradable and are candidates for biological treatment (Chauhan et al., 2012; Qing and Wyman, 2011). The salinity added by inorganic breakers suggests the need for RO for their efficient removal. Enzymes are likely candidates for removal by either NF or 
RO due to their large molecular structures, although bio-fouling potential may be increased in membrane systems.

\subsection{Treatability of Clay Stabilizers}

Clay stabilizers consist of ammonium compounds, including salts and organic polymeric chemicals. The most common clay stabilizer in California was 1,2-ethanediaminium, N1,N2bis[2-[bis(2-hydroxyethyl)methylammonio]ethyl]-N1,N2-bis(2-hydroxyethyl)-N1,N2-dimethyl,chloride (1:4) (138879-94-4), a large molecule (506.14 $\left.\mathrm{g} \mathrm{mol}^{-1}\right)$ used in $66 \%$ of treatments. None of the clay stabilizers are volatile based on $\log K_{H}$ data; however, ammonium ions can be volatilized to ammonia for removal. None of the clay stabilizers have $\log K_{o w}$ values that would suggest removal by adsorption although three of the clay stabilizers [ammonium chloride (12125-02-9), 2-propen-1-aminium, N,N-dimethyl-N-2-propen-1-yl-, $\quad$ chloride $\quad(1: 1)$, homopolymer (26062-79-3), and ammonium sulfate (7783-20-2)] have high enough $\log K_{o c}$ values to suggest sorption onto organic particles. As mentioned above, ammonium ions can be removed via activated carbon adsorption, biological treatment and NF or RO. Choline chloride (67-48-1), a QAC used for clay stabilization, is readily biodegradable, making it a candidate for removal by biological treatment. Based on molecular weights, polymeric clay stabilizers and choline chloride would likely be removed in NF or RO while RO would be necessary for removal of inorganic salts.

\subsection{Treatability of Corrosion Inhibitors}

Corrosion inhibitors consist of organic chemicals that include formaldehyde polymers, chelating agents, and other chemicals (propargyl alcohol and thioglycolic acid). The use of formaldehyde polymers in corrosion control is well-documented (Singh et al., 2014) although

fate in treatment systems - including degradation pathways and the resulting by-products — does 
not appear well known. None of the corrosion inhibitors were used in more than $3 \%$ of hydraulic fracturing treatments in California. Based on $\log K_{H}$ and $\log K_{o w}$ data, corrosion inhibitors are not candidates for removal by volatilization, adsorption, or partitioning into the oil fraction for removal in oil-water separators. The $\log K_{o c}$ values indicate half of the corrosion inhibitors will sorb onto organic particles.

Biodegradability data are mixed for the corrosion inhibitors, indicating some potential for removal in biological treatment. Sodium erythorbate (6381-77-7) is biodegradable, while propargyl alcohol, thioglycolic acid, and trisodium nitrilotriacetate (5064-31-3) are somewhat biodegradable and EDTA compounds [tetrasodium ethylenediaminetetraacetate (64-02-8) and trisodium ethylenediaminetetraacetate (150-38-9)] are recalcitrant (Bernhard et al., 2006; Sykora et al., 2001; U.S. EPA, 1989). Four formaldehyde polymers were identified: 4,1,1-dimethylethyl phenolmethyl oxirane (29316-47-0), formaldehyde, polymer with 2-methyloxirane, 4nonylphenol and oxirane (63428-92-2), formaldehyde, polymer with 4-nonylphenol and oxirane (30846-35-6), and thiourea, polymer with formaldehyde and 1-phenylethanone (68527-49-1).

Only two of the corrosion inhibitors have molecular weights less than $100 \mathrm{~g} \mathrm{~mol}^{-1}$, propargyl alcohol (107-19-7) and thioglycolic acid (68-11-1), suggesting that most of the corrosion inhibitors would be removed by either NF or RO. Given that the corrosion inhibitors are organic, electrocoagulation and advanced oxidation may be appropriate-additional study is warranted.

\subsection{Treatability of Crosslinkers}

The most commonly used crosslinkers in California were boron compounds (e.g. boron sodium oxide, sodium tetraborate decahydrate, zirconium oxychloride), which were used in $92 \%$ of treatments. Organic crosslinkers were also used. None of the crosslinkers have $\log K_{H}$ values that suggest removal by volatilization. Based on $\log K_{o w}$ data, only zirconium oxychloride (7699- 
43-6) is a candidate for removal by adsorption or partitioning into the oil fraction. Five of the crosslinkers have $\log K_{o c}$ values high enough to suggest sorption onto organic particles.

Only two of the organic crosslinkers have data indicating biodegradability and possible removal in biological treatment: D-glucitol (50-70-4) and glyoxal (107-22-2). Given that most crosslinkers are inorganic salts, desalination appears most appropriate for removal. Based on molecular weight data, four of the crosslinkers could be removed by NF while three of the crosslinkers have molecular weights below the MWCO for RO: boric acid (10043-35-3), glyoxal (107-22-2), and boron oxide (1303-86-2). Removal of boron compounds by RO is improved by first raising the $\mathrm{pH}$ above 10 to convert compounds to borate (Xu and Jiang, 2008). Ion exchange resins can also be used for boron removal (Xu and Jiang, 2008). Electrocoagulation, conventional coagulation, and other technologies appear effective for boron removal although further demonstration is needed (Ezechi et al., 2014; Xu and Jiang, 2008).

\subsection{Treatability of Friction Reducers}

No friction reducers were identified in the dataset. Friction reducers are used infrequently in California because cross-linked gelled treatments are preferred over slickwater treatments due to geologic conditions(CCST, 2015). Three friction reducers were identified without CASRN: a polyacrylamide copolymer, a polyacrylate, and a non-specified commercial product.

Polyacrylamide can be removed using biological treatment (Liu et al., 2012), or advanced oxidation (Lu et al., 2012). Polyacrylamides and the associated polymers are used as coagulants (Chatterjee et al., 2009), and as adsorbents (Rahchamani et al., 2011), so coagulation and adsorption based treatment methods are likely to be effective. Membrane treatments, such as NF and RO, may be impractical due to bio-fouling (Matin et al., 2011). 


\subsection{Treatability of Gelling Agents}

Only one gelling agent was identified, guar gum (9000-30-0), which was used in $97 \%$ of treatments. Guar gum adsorbs onto media (Liu et al., 2000), although adsorption-based removal may be impractical due to media clogging. Guar gum is readily biodegradable (Lester et al., 2013) and contributes to the oxygen demand of produced water from fractured wells (Stringfellow et al., 2014; Thacker et al., 2015), suggesting that biological treatment is appropriate for its removal (Kekacs et al., 2015; Lester et al., 2015; Strong et al., 2014). Guar gum is a natural flocculant (Singh et al., 2000), so coagulation-flocculation methods are likely effective for removal. However, chemical treatments are only practical when guar gum is present in low concentrations (50-300 mg L $\left.\mathrm{L}^{-1}\right)$; highly concentrated gelled fluids (>5000 $\mathrm{mg} \mathrm{L}^{-1}$ ) require excessive chemical doses (Evans et al., 2014). Membrane-based treatment (in NF or RO systems) may be impractical due to bio-fouling (Matin et al., 2011).

\subsection{Treatability of Iron Control Agents}

Iron control agents, used in $16 \%$ of treatments, consist of organic acids and bases that function as chelating agents. With the exception of recalcitrant EDTA compounds [tetrasodium ethylenediaminetetraacetate (64-02-8) and trisodium ethylenediaminetetraacetate (150-38-9)], most iron control agents are carboxylic acids that are readily biodegradable including acetic acid (64-19-7), citric acid (77-92-9), erythorbic acid (89-65-6), thioglycolic acid (68-11-1), and sodium erythorbate (6381-77-7). The prevalence of carboxylic acids in fracturing fluids is evident by the large quantity of acetic acid observed in produced water from fractured wells that increases oxygen demand (Lester et al., 2015). Trisodium nitrilotriacetate (5064-31-3) is somewhat biodegradable and may be partially removed in treatment systems (Bernhard et al., 2006; Sykora et al., 2001). Six of the eight iron control agents have $\log K_{o c}$ values suggesting 
sorption onto organic particles, although removal by adsorption and oil-partitioning is not suggested by $\log K_{\text {ow }}$ values.

\subsection{Treatability of Scale Inhibitors}

Scale inhibitors, used in $60 \%$ of treatments, consisted mostly of organic chemicals, although two inorganic chemicals were also listed. The most commonly used scale inhibitor was phosphonic acid (13598-36-2), used in $49 \%$ of treatments. The $\log K_{o w}$ and $\log K_{H}$ data of the scale inhibitors do not suggest removal by adsorption or volatilization. Six of the seven chemicals have $\log K_{o c}$ values that suggest sorption onto organic particles. Although phosphonic acid and its salts adhere to biological flocs, they are not readily biodegradable (Nowack, 1998).

Carboxylic acids used as scale inhibitors are biodegradable (e.g. sodium erythorbate (6381-77-7)) although EDTA compounds are recalcitrant and nitrilotriacetate (NTA) compounds have limited biodegradability (Bernhard et al., 2006; Sykora et al., 2001). All but two of the scale inhibitors [phosphonic acid (13598-36-2) and 2-propenoic acid/ammonium salt (1:1) (10604-69-0)] have molecular weights higher than $100 \mathrm{~g} \mathrm{~mol}^{-1}$, suggesting efficient removal by either NF or RO.

\subsection{Treatability of Solvents}

Solvents were used in $99 \%$ of treatments in California. Frequently used solvents include ethylene glycol (107-21-1), hydrotreated light petroleum distillates (64742-47-8), and hydrotreated light petroleum distillates, paraffinic (64742-55-8). Of the 36 solvents identified, 11 have $\log K_{H}$ values high enough to suggest removal by volatilization. Fifteen of the solvents have $\log K_{o w}$ values that suggest adsorption onto media or removal by partitioning into the oil fraction. Many of the solvents with high $\log K_{\text {ow }}$ values are hydrocarbon-based solvents. Seventeen of the solvents have $\log K_{o c}$ data that indicates adsorption onto organic particles. 
Twenty-four of the solvents have data indicating biodegradability. Biological treatment is generally effective for solvents provided that the microbial consortia is appropriate (Margesin and Schinner, 2001). Biological treatment of solvents can be improved by oxidative pretreatments (Nam et al., 2001).

\subsection{Treatability of Surfactants}

Surfactants were used in $95 \%$ of treatments in California. The most commonly used surfactant was isotridecanol, ethoxylated (9043-30-5), used in 72\% of treatment. Of the 44 surfactants identified, eight have $\log K_{H}$ values high enough to suggest removal by volatilization. Twenty-five of the surfactants have $\log K_{\text {ow }}$ values high enough to suggest removal by adsorption or partitioning into the oil fraction for removal. Many of the surfactants with high $\log K_{\text {ow }}$ values are ethoxylated surfactants.

Sixteen of the surfactants are biodegradable, suggesting biological treatment would be appropriate. Treatment of surfactants has been demonstrated using advanced oxidation (Ikehata and El-Din, 2004; Lin et al., 1999), biological treatment (Di Gioia et al., 2008), and biological treatment combined with oxidative pre-treatments (Nakai et al., 2015).

\section{Discussion}

\subsection{Dissolved Air/Gas Flotation}

Only $10 \%$ of the hydraulic fracturing chemicals with data are volatile enough for efficient removal by dissolved air/gas flotation. The low volatility of hydraulic fracturing chemicals stems from the fact that most additives are salts, gelling agents, acids/bases, polymers, resins, etc. that are not volatile. Although solvents are used extensively in fluid formulations, the volatility of these solvents is not sufficiently high enough to warrant removal by volatilization. Minimal volatilization of fracturing fluids is consistent with the results of Kekacs et al. (2015) where 
volatilization of organic carbon accounted for only $7 \%$ of carbon loss in biodegraded hydraulic fracturing fluid mixtures.

Despite the low volatility of hydraulic fracturing chemicals, dissolved air/gas flotation is likely to be used for produced water treatment to remove conventional contaminants (Arthur et al., 2005; M-I SWACO, 2012). Removal of trace chemicals in air/gas flotation could be improved by upstream chemical addition (Crittenden et al., 2012). An immiscible layer at the water surface could further increase removal of contaminants in dissolved air/gas flotation units (Bayati et al., 2011; Thoma et al., 1999).

\subsection{Adsorption}

Only one-third of hydraulic fracturing chemicals with data are candidates for removal by adsorption or partitioning into oil for removal. Adsorption potential onto organic surfaces is slightly less expected - only $22 \%$ of chemical additives with data are expected to sorb onto organic surfaces. Although adsorption-based technologies (e.g. activated carbon) are effective for many organic contaminants (Crittenden et al., 1999), adsorption-based treatment is only partially effective here. Prediction of adsorption potential could be improved using quantitative structure-property relationships (Blum et al., 1994; de Ridder et al., 2010; Magnuson and Speth, 2005). Modeling and experimental data could also provide better predictions of equilibrium contaminant loading onto adsorptive media (Crittenden et al., 1999), although realistic estimates of media life would need to be done using field trials. An adsorption media successfully demonstrated for conventional produced water is surfactant-modified zeolite, which removes hydrocarbons and is regenerated with air sparging (Altare et al., 2007; Kwon et al., 2011; Ranck et al., 2005) — this media should be investigated for its ability to remove hydraulic fracturing chemicals. 


\subsection{Biological Treatment}

Thirty-seven percent of organic chemical additives were biodegradable in bench-scale tests, suggesting these additives would be removed in biological treatment (Struijs and Vandenberg, 1995). Preliminary investigations of produced water from fractured wells indicate biodegradability, even with high salinity and trace toxicants present (Kahrilas et al., 2015; Lester et al., 2013; Strong et al., 2014). Produced water from fractured wells contains high oxygen demand and microbial populations capable of degrading the organic matter present, suggesting the suitability of biological treatment (Cluff et al., 2014; Mohan et al., 2013a; Mohan et al., 2013b).

Biological treatment has been demonstrated for many saline wastewaters, including conventional produced water (Janson et al., 2015; Kose et al., 2012; Kwon et al., 2011; Li et al., 2010). Biological treatment of saline wastewaters is possible under both aerobic and anaerobic conditions provided that an appropriate halophilic bacterial consortium is present (Xiao and Roberts, 2010). Biological treatment has been demonstrated in conventional produced water for salt concentrations up to $100,000 \mathrm{mg} / \mathrm{L}$ TDS, although removal efficiency decreases with increasing salinity (Pendashteh et al., 2012). The salinity of produced water from manyalthough not all—fractured wells is less than 100,000 mg/L TDS (Barbot et al., 2013), low enough to permit biological treatment. Although residual chemical additives such as biocides can contribute toxicity that interfere with biological processes (Kahrilas et al., 2015; Kassotis et al., 2014; Maguire-Boyle and Barron, 2014; Orem et al., 2014), biological treatment remains possible in the presence of toxicants such as DDAC at concentrations up to $80 \mathrm{mg} / \mathrm{L}$ (Laopaiboon et al., 2002). Fixed-film treatment technologies (Laopaiboon et al., 2002;

Laopaiboon et al., 2008; Laopaiboon et al., 2001) and microbial acclimation can improve 
treatment efficacy (Leung, 2001). Various forms of biological treatment systems - utilizing combinations of reactor designs - appear promising for contaminants in produced water: an example is two-phase partitioning bioreactors that allow for biodegradation of recalcitrant substrates (Piemonte et al., 2016; Tomei et al., 2012).

\subsection{Reverse Osmosis}

The most universally applicable treatment method for produced water from fractured wells is RO, based on its ability to remove most compounds (Alzahrani et al., 2013; Malaeb and Ayoub, 2011). RO is effective for reducing salts in produced water ( $\mathrm{Xu}$ et al., 2008). Given that RO fouling is a major problem with high-strength organic wastewaters (Matin et al., 2011; Mondal and Wickramasinghe, 2008; Xu and Drewes, 2006), alternatives such as nanofiltration (NF), low-pressure RO, and forward osmosis have been rigorously pursued (Mondal and Wickramasinghe, 2008; Thiel et al., 2015; Xu and Drewes, 2006), as have combinations of these technologies (Shanmuganathan et al., 2015). The alternatives are not as efficient as RO (Thiel et al., 2015), suggesting that extensive pre-treatment followed by RO may be most appropriate treatment (Cakmakci et al., 2008; Ozgun et al., 2013; Pramanik et al., 2015; Shanmuganathan et al., 2015). Pre-treatment is used to reduce particulate matter, minerals, and organics that can cause scaling and bio-fouling on membrane surfaces (Gregory et al., 2011; He et al., 2014; Shaffer et al., 2013). Candidate pre-treatment technologies are biological treatment, microfiltration, activated carbon, etc.

Contaminant removal in $\mathrm{RO}$ is a function of contaminant properties, membrane properties, and feed water quality (Malaeb and Ayoub, 2011). Physical-chemical properties (e.g. molecular weight, hydrophobicity) are useful for predicting removal by RO and NF (Bellona et al., 2004; Chen et al., 2004; Kiso et al., 2001; Van der Bruggen et al., 1999). Modeling and 
bench-scaling testing can confirm preliminary predictions (Shahmansouri and Bellona, 2013). Based on the molecular weights of chemical additives and a molecular weight cut-off (MWCO) of $100 \mathrm{~g} \mathrm{~mol}^{-1}$ for RO membranes (Dow Chemical, 2015a), approximately $70 \%$ of organic chemical additives are expected to be rejected by RO (Figure 4). In contrast, only $26 \%$ of organic chemicals are expected to be rejected by NF membranes, given a MWCO of 200-300 g/mole (Dow Chemical, 2015b). Actual removal rates will vary based on membrane fouling, which affects effective pore size and membrane surface charge (Xu et al., 2006). Removal rates of inorganic compounds will vary according to the extent of ionization, which is altered according to $\mathrm{pH}$. For example, boron removal by RO is improved at higher $\mathrm{pH}$ (Alzahrani et al., 2013; Cengeloglu et al., 2008).

\subsection{Emerging Technologies}

Technologies under development for treatment of conventional produced water could be effective for treating hydraulic fracturing wastes (Arthur et al., 2005; Fakhru'l-Razi et al., 2009; M-I SWACO, 2012). Some of these technologies lack full-scale demonstration.

Electrocoagulation is currently under development—it can reduce COD, trace metals, and boron from produced water (Esmaeilirad et al., 2015; Ezechi et al., 2014). Evaporation-based desalination methods [e.g. mechanical vapor compression (MVP)] are also being developed for treatment of produced water although the economic feasibility of such technologies is not certain. Advanced oxidation is useful for oxidizing recalcitrant trace organics (Liu et al., 2009), and could be useful for oxidizing hydraulic fracturing additives (Stringfellow et al., 2014). Advanced oxidation can remove polyacrylamide (Lu et al., 2012), an additive used nationally (U.S. EPA, 2015b) although not frequently used in California (Stringfellow et al., 2015). Advanced oxidation can remove chelating agents (Sillanpaa et al., 2011), which are used 
extensively in oil/gas production for control of iron, scaling, and corrosion (Stringfellow et al., 2015). Duran-Moreno et al. (2011) used advanced oxidation to improve the efficacy of biological treatment of oil refinery wastewater - a similar approach could be used for produced water from fractured wells.

\section{Conclusions}

Physical-chemical data available for hydraulic fracturing chemicals indicate these chemicals are largely treatable using combinations of treatment technologies. However the most common, currently-applied treatment technologies (gravity separation, sedimentation, gas floatation, and filtration) are unlikely to remove significant amounts of hydraulic fracturing chemicals. Biological treatment appears a viable choice for reducing oxygen demand and removing many hydraulic fracturing chemicals. Reverse osmosis or evaporation-based technologies are appropriate choices for desalination. Nanofiltration does not appear to be a viable treatment since it is only predicted to remove a portion of the hydraulic fracturing chemicals. Advanced oxidation and electrocoagulation are promising technologies although demonstration is needed. Further research and pilot studies are needed demonstrated removal of hydraulic fracturing chemicals in produced water during treatment, especially prior to beneficial reuse that results in environmental release.

\section{Acknowledgements}

This work was supported by the California Natural Resources Agency under Work for Others Agreements and by Laboratory Directed Research and Development (LDRD) funding from Berkeley Lab, provided by the Director, Office of Science, of the U.S. Department of Energy under Contract No. DE-AC02-05CH1123 


\section{References}

Abualfaraj, N., Gurian, P.L., Olson, M.S., 2014. Characterization of Marcellus Shale Flowback Water. Environmental Engineering Science 31, 514-524.

Altare, C.R., Bowman, R.S.B., Katz, L.E., Kinney, K.A., Sullivan, E.J., 2007. Regeneration and long-term stability of surfactant-modified zeolite for removal of volatile organic compounds from produced water. Microporous and Mesoporous Materials 105, 305-316.

Alzahrani, S., Mohammad, A.W., Hilal, N., Abdullah, P., Jaafar, O., 2013. Comparative study of $\mathrm{NF}$ and RO membranes in the treatment of produced water-Part I: Assessing water quality. Desalination 315, 18-26.

Arthur, D.J., Langhus, B.G., Patel, C., 2005. Technical Summary of Oil \& Gas Produced Water Treatment Technologies. ALL Consulting, LLC, Tulsa, OK.

Barbot, E., Vidic, N.S., Gregory, K.B., Vidic, R.D., 2013. Spatial and temporal correlation of water quality parameters of produced waters from Devonian-age shale following hydraulic fracturing. Environ. Sci. Technol. 47, 2562-2569.

Bayati, F., Shayegan, J., Noorjahan, A., 2011. Treatment of oilfield produced water by dissolved air precipitation/solvent sublation. Journal of Petroleum Science and Engineering 80, 26-31.

BCC Research LLC, 2012. Markets for Produced Water Treatment Equipment Outside North America (Report Code: ENV015A). BCC Research LLC, Wellesley, MA.

Bellona, C., Drewes, J.E., Xu, P., Amy, G., 2004. Factors affecting the rejection of organic solutes during NF/RO treatment - a literature review. Water Research 38, 2795-2809.

Bernhard, M., Muller, J., Knepper, T.R., 2006. Biodegradation of persistent polar pollutants in wastewater: Comparison of an optimised lab-scale membrane bioreactor and activated sludge treatment. Water Research 40, 3419-3428.

Blum, D.J.W., Suffet, I.H., Duguet, J.P., 1994. Quantitative structure-activity relationship using molecular connectivity for the activated carbon adsorption of organic-chemicals in water. Water Research 28, 687-699. 
Boopathy, R., Karthikeyan, S., Mandal, A.B., Sekaran, G., 2013. Adsorption of ammonium ion by coconut shell-activated carbon from aqueous solution: kinetic, isotherm, and thermodynamic studies. Environmental Science and Pollution Research 20, 533-542.

Cakmakci, M., Kayaalp, N., Koyuncu, I., 2008. Desalination of produced water from oil production fields by membrane processes. Desalination 222, 176-186.

CCST, 2015. An Independent Scientic Assessment of Well Stimulation in California, Volume 1: Well Stimulation Technologies and their Past, Present, and Potential Future Use in California. Retrieved from http://ccst.us/projects/hydraulic_fracturing_public/SB4.php. Prepared for: California Natural Resources Agency. Prepared by: California Council on Science and Technology (CCST), Lawrence Berkeley National Laboratory, Pacific Institute, and Dr. Donald Gautier, LLC. CCST, Sacramento, CA.

Cengeloglu, Y., Arslan, G., Tor, A., Kocak, I., Dursun, N., 2008. Removal of boron from water by using reverse osmosis. Separation and Purification Technology 64, 141-146.

Chapman, E.C., Capo, R.C., Stewart, B.W., Kirby, C.S., Hammack, R.W., Schroeder, K.T., Edenborn, H.M., 2012. Geochemical and strontium isotope characterization of produced waters from Marcellus Shale natural gas extraction. Environmental Science \& Technology 46, 35453553.

Chatterjee, T., Chatterjee, S., Lee, D.S., Lee, M.W., Woo, S.H., 2009. Coagulation of soil suspensions containing nonionic or anionic surfactants using chitosan, polyacrylamide, and polyaluminium chloride. Chemosphere $75,1307-1314$.

Chauhan, P.S., Puri, N., Sharma, P., Gupta, N., 2012. Mannanases: microbial sources, production, properties and potential biotechnological applications. Applied Microbiology and Biotechnology 93, 1817-1830.

Chen, S.S., Taylor, J.S., Mulford, L.A., Norris, C.D., 2004. Influences of molecular weight, molecular size, flux, and recovery for aromatic pesticide removal by nanofiltration membranes. Desalination 160, 103-111.

Choi, J.S., Kang, S.R., Lee, S.S., Joo, H.J., 2015. Effects of biological treatment in reverse osmosis concentrate with non-oxidizing biocide (DBNPA) content. Desalination and Water Treatment 53, 2403-2411.

Clark, C.E., Veil, J.A., 2009. Produced water volumes and management practices in the United States. Argonne National Laboratory (ANL), Environmental Science Division. 
Cluff, M.A., Hartsock, A., MacRae, J.D., Carter, K., Mouser, P.J., 2014. Temporal changes in microbial ecology and geochemistry in produced water from hydraulically fractured Marcellus shale gas wells. Environmental Science \& Technology 48, 6508-6517.

Colorado School of Mines, 2009. An Integrated Framework for Treatment and Management of Produced Water: Technical assessment of produced water treatment technologies, 1 ed. Colorado School of Mines, Golden, CO, p. 157.

Crittenden, J.C., Sanongraj, S., Bulloch, J.L., Hand, D.W., Rogers, T.N., Speth, T.F., Ulmer, M., 1999. Correlation of aqueous-phase adsorption isotherms. Environmental Science \& Technology 33, 2926-2933.

Crittenden, J.C., Trussell, R.R., Hand, D.W., Howe, K.J., Tchobanoglous, G., 2012. MWH's Water Treatment: Principles and Design. John Wiley \& Sons, Hoboken, New Jersey.

Dallbauman, L., Sirivedhin, T., 2005. Reclamation of produced water for beneficial use. Separation Science and Technology 40, 185-200.

de Ridder, D.J., Villacorte, L., Verliefde, A.R.D., Verberk, J., Heijman, S.G.J., Amy, G.L., van Dijk, J.C., 2010. Modeling equilibrium adsorption of organic micropollutants onto activated carbon. Water Research 44, 3077-3086.

Di Gioia, D., Michelles, A., Pierini, M., Bogialli, S., Fava, F., Barberio, C., 2008. Selection and characterization of aerobic bacteria capable of degrading commercial mixtures of lowethoxylated nonylphenols. Journal of Applied Microbiology 104, 231-242.

Doronina, N.V., Ezhov, V.A., Trotsenko, Y.A., 1997. Aerobic biodegradation of formaldehyde, methanol, and methylamine by immobilized Methylobacterium extorquens cells. Applied Biochemistry and Microbiology 33, 138-141.

Dow Chemical, 2015a. Product Information: FilmTEC Membranes - FT30 Reverse Osmosis Membrane Specifications. Form No. 609-01020-0406.

Dow Chemical, 2015b. Tech Fact: DOW FilmTEC Membranes - Estimated Percent Rejection of Various Solutes by DOW FilmTEC Membranes. Form No. 609-00240-0311.

Duran-Moreno, A., Garcia-Gonzalez, S.A., Gutierrez-Lara, M.R., Rigas, F., Ramirez-Zamora, R.M., 2011. Assessment of Fenton's reagent and ozonation as pre-treatments for increasing the 
biodegradability of aqueous diethanolamine solutions from an oil refinery gas sweetening process. Journal of Hazardous Materials 186, 1652-1659.

Esmaeilirad, N., Carlson, K., Ozbek, P.O., 2015. Influence of softening sequencing on electrocoagulation treatment of produced water. Journal of Hazardous Materials 283, 721-729.

European Chemicals Agency (ECHA), 2000. International Uniform Chemical Information Database (IUCLID), CD-ROM Year 2000 Edition.

Evans, R., Porter, F., Eaton, B., Muth, M., 2014. Chemical pretreatment of guar gum-based hydraulic fracturing solutions and produced water. Oil and Gas Facilities 3, 8-11.

Ezechi, E.H., Isa, M.H., Kutty, S.R.M., Yaqub, A., 2014. Boron removal from produced water using electrocoagulation. Process Safety and Environmental Protection 92, 509-514.

Fakhru'l-Razi, A., Pendashteh, A., Abdullah, L.C., Biak, D.R.A., Madaeni, S.S., Abidin, Z.Z., 2009. Review of technologies for oil and gas produced water treatment. Journal of Hazardous Materials 170, 530-551.

Faksness, L.G., Grini, P.G., Daling, P.S., 2004. Partitioning of semi-soluble organic compounds between the water phase and oil droplets in produced water. Marine Pollution Bulletin 48, 731742 .

Ferrer, I., Thurman, E.M., 2015a. Analysis of hydraulic fracturing additives by LC/Q-TOF-MS. Analytical and Bioanalytical Chemistry 407, 6417-6428.

Ferrer, I., Thurman, E.M., 2015b. Chemical constituents and analytical approaches for hydraulic fracturing waters. Trends in Environmental Analytical Chemistry 5, 18-25.

Gregory, K., Mohan, A.M., 2015. Current perspective on produced water management challenges during hydraulic fracturing for oil and gas recovery. Environmental Chemistry 12, 261-266.

Gregory, K.B., Vidic, R.D., Dzombak, D.A., 2011. Water management challenges associated with the production of shale gas by hydraulic fracturing. Elements 7, 181-186. 
Guerra, K., Dahm, K., Dundorf, S., 2011. Oil and Gas Produced Water Management and Beneficial Use in the Western United States, S\&T Report No. 157. U.S. Department of the Interior, Bureau of Reclamation, Denver, CO.

Haluszczak, L.O., Rose, A.W., Kump, L.R., 2013. Geochemical evaluation of flowback brine from Marcellus gas wells in Pennsylvania, USA. Appl. Geochem. 28, 55-61.

Hayrynen, K., Pongracz, E., Vaisanen, V., Pap, N., Manttari, M., Langwaldt, J., Keiski, R.L., 2009. Concentration of ammonium and nitrate from mine water by reverse osmosis and nanofiltration. Desalination 240, 280-289.

He, C., Wang, X.H., Liu, W.S., Barbot, E., Vidic, R.D., 2014. Microfiltration in recycling of Marcellus Shale flowback water: Solids removal and potential fouling of polymeric microfiltration membranes. Journal of Membrane Science 462, 88-95.

Igunnu, E.T., Chen, G.Z., 2012. Produced water treatment technologies. International Journal of Low-Carbon Technologies Published online, doi:10.1093/ijlct/cts049, 1-21.

Ikehata, K., El-Din, M.G., 2004. Degradation of recalcitrant surfactants in wasterwater by ozonation and advances oxidation processes: A review. Ozone-Science \& Engineering 26, 327343.

Jacobson, A., Williams, T.M., 2000. The environmental fate of isothiazolone biocides. Chimica Oggi-Chemistry Today 18, 105-108.

Janson, A., Santos, A., Katebah, M., Hussain, A., Minier-Matar, J., Judd, S., Adham, S., 2015. Assessing the biotreatability of produced water from a Qatari gas field. SPE Journal 20, 11131119.

Jiang, Q.Y., Rentschler, J., Perrone, R., Liu, K.L., 2013. Application of ceramic membrane and ion-exchange for the treatment of the flowback water from Marcellus shale gas production. $J$. Membrane Sci. 431, 55-61.

Kahrilas, G.A., Blotevogel, J., Stewart, P.S., Borch, T., 2015. Biocides in hydraulic fracturing fluids: A critical review of their usage, mobility, degradation, and toxicity. Environmental Science \& Technology 49, 16-32. 
Kassotis, C.D., Tillitt, D.E., Davis, J.W., Hormann, A.M., Nagel, S.C., 2014. Estrogen and androgen receptor activities of hydraulic fracturing chemicals and surface and ground water in a drilling-dense region. Endocrinology 155, 897-907.

Kekacs, D., Drollette, B.D., Brooker, M., Plata, D.L., Mouser, P.J., 2015. Aerobic biodegradation of organic compounds in hydraulic fracturing fluids. Biodegradation.

Kiso, Y., Sugiura, Y., Kitao, T., Nishimura, K., 2001. Effects of hydrophobicity and molecular size on rejection of aromatic pesticides with nanofiltration membranes. Journal of Membrane Science 192, 1-10.

Kose, B., Ozgun, H., Ersahin, M.E., Dizge, N., Koseoglu-Imer, D.Y., Atay, B., Kaya, R., Altinbas, M., Sayili, S., Hoshan, P., Atay, D., Eren, E., Kinaci, C., Koyuncu, I., 2012. Performance evaluation of a submerged membrane bioreactor for the treatment of brackish oil and natural gas field produced water. Desalination 285, 295-300.

Kreuzinger, N., Fuerhacker, M., Scharf, S., Uhl, M., Gans, O., Grillitsch, B., 2007. Methodological approach towards the environmental significance of uncharacterized substances - Quaternary ammonium compounds as an example. Desalination 215, 209-222.

Kwon, S., Sullivan, E.J., Katz, L.E., Bowman, R.S., Kinney, K.A., 2011. Laboratory and field evaluation of a pretreatment system for removing organics from produced water. Water Environ. Res. 83, 843-854.

Laopaiboon, L., Hall, S.J., Smith, R.N., 2002. The effect of a quaternary ammonium biocide on the performance and characteristics of laboratory-scale rotating biological contactors. Journal of Applied Microbiology 93, 1051-1058.

Laopaiboon, L., Phukoetphim, N., Vichitphan, K., Laopaiboon, P., 2008. Biodegradation of an aldehyde biocide in rotating biological contactors. World Journal of Microbiology \& Biotechnology 24, 1633-1641.

Laopaiboon, L., Smith, R.N., Hall, S.J., 2001. A study of the effect of isothiazolones on the performance and characteristics of a laboratory-scale rotating biological contactor. Journal of Applied Microbiology 91, 93-103.

Lester, Y., Ferrer, I., Thurman, E.M., Sitterley, K.A., Korak, J.A., Aiken, G., Linden, K.G., 2015. Characterization of hydraulic fracturing flowback water in Colorado: Implications for water treatment. Science of the Total Environment 512, 637-644. 
Lester, Y., Yacob, T., Morrissey, I., Linden, K.G., 2013. Can we treat hydraulic fracturing flowback with a conventional biological process? The case of guar gum. Environmental Science and Technology Letters, DOI: 10.1021/ez4000115.

Leung, H.-W., 2001. Ecotoxicology of glutaraldehyde: review of environmental fate and effects studies. Ecotoxicology and environmental safety 49, 26-39.

Li, G., Guo, S.H., Li, F.M., 2010. Treatment of oilfield produced water by anaerobic process coupled with micro-electrolysis. Journal of Environmental Sciences-China 22, 1875-1882.

Lin, S.H., Lin, C.M., Leu, H.C., 1999. Operating characteristics and kinetic studies of surfactant wastewater treatment by fenton oxidation. Water Research 33, 1735-1741.

Liske, R.A., Leong, L.Y.C., 2006. Final Report: Beneficial Reuse of San Ardo Produced Water.

Liu, A.Y., Liu, S.Y., 2016. Study on performance of three backwashing modes of filtration media for oilfield wastewater filter. Desalination and Water Treatment 57, 10498-10505.

Liu, L., Wang, Z., Lin, K., Cai, W., 2012. Microbial degradation of polyacrylamide by aerobic granules. Environmental Technology 33, 1049-1054.

Liu, Q., Zhang, Y.H., Laskowski, J.S., 2000. The adsorption of polysaccharides onto mineral surfaces: an acid/base interaction. International Journal of Mineral Processing 60, 229-245.

Liu, Z.H., Kanjo, Y., Mizutani, S., 2009. Removal mechanisms for endocrine disrupting compounds (EDCs) in wastewater treatment - physical means, biodegradation, and chemical advanced oxidation: A review. Science of the Total Environment 407, 731-748.

Lu, M., Wu, X., Wei, X., 2012. Chemical degradation of polyacrylamide by advanced oxidation processes. Environmental Technology 33, 1021-1028.

M-I SWACO, 2012. Fracturing Fluid Flowback Reuse Project: Decision Tree \& Guidance Manual. Petroleum Technology Alliance of Canada, Science and Community Environmental Knowledge.

Magnuson, M.L., Speth, T.F., 2005. Quantitative structure - Property relationships for enhancing predictions of synthetic organic chemical removal from drinking water by granular activated carbon. Environmental Science \& Technology 39, 7706-7711. 
Maguire-Boyle, S.J., Barron, A.R., 2014. Organic compounds in produced waters from shale gas wells. Environmental Science-Processes \& Impacts 16, 2237-2248.

Malaeb, L., Ayoub, G.M., 2011. Reverse osmosis technology for water treatment: State of the art review. Desalination 267, 1-8.

Margesin, R., Schinner, F., 2001. Biodegradation and bioremediation of hydrocarbons in extreme environments. Applied Microbiology and Biotechnology 56, 650-663.

Matin, A., Khan, Z., Zaidi, S.M.J., Boyce, M.C., 2011. Biofouling in reverse osmosis membranes for seawater desalination: Phenomena and prevention. Desalination 281, 1-16.

Mohan, A.M., Hartsock, A., Bibby, K.J., Hammack, R.W., Vidic, R.D., Gregory, K.B., 2013a. Microbial community changes in hydraulic fracturing fluids and produced water from shale gas extraction. Environmental Science \& Technology 47, 13141-13150.

Mohan, A.M., Hartsock, A., Hammack, R.W., Vidic, R.D., Gregory, K.B., 2013b. Microbial communities in flowback water impoundments from hydraulic fracturing for recovery of shale gas. FEMS Microbiol. Ecol. 86, 567-580.

Mondal, S., Wickramasinghe, S.R., 2008. Produced water treatment by nanofiltration and reverse osmosis membranes. Journal of Membrane Science 322, 162-170.

Nakai, S., Okuda, T., Nishijima, W., Okada, M., 2015. Production of mono- and di-carboxylated polyethylene glycols as a factor obstacle to the successful ozonation-assisted biodegradation of ethoxylated compounds. Chemosphere 136, 153-159.

Nam, K., Rodriguez, W., Kukor, J.J., 2001. Enhanced degradation of polycyclic aromatic hydrocarbons by biodegradation combined with a modified Fenton reaction. Chemosphere 45, $11-20$.

National Library of Medicine, 2013a. ChemIDplus Advanced: A TOXNET Database. http://chem.sis.nlm.nih.gov/chemidplus/. National Institute of Health, Bethesda, MD.

National Library of Medicine, 2013b. Hazardous Substances Data Bank: A TOXNET Database. National Institute of Health. 
National Library of Medicine, 2013c. Toxicology Data Network (TOXNET) Hazardous Substance Data Bank (HSDB).

Nowack, B., 1998. The behavior of phosphonates in wastewater treatment plants of Switzerland. Water Research 32, 1271-1279.

NYS DEC, 2011. Revised Draft Supplemental Generic Environmental Impact Statement on the Oil, Gas and Solution Mining Regulatory Program, Well Permit Issuance for Horizontal Drilling And High-Volume Hydraulic Fracturing in the Marcellus Shale and Other Low-Permeability Gas Reservoirs. New York State Department of Environmental Conservation, Albany, NY.

Orem, W., Tatu, C., Varonka, M., Lerch, H., Bates, A., Engle, M., Crosby, L., McIntosh, J., 2014. Organic substances in produced and formation water from unconventional natural gas extraction in coal and shale. International Journal of Coal Geology 126, 20-31.

Orr, G., 2011. Produced Water Treatment and Re-use: A Californian Case Study, Tekna Produced Water Management Conference 2011, Stavanger, Norway.

Ozgun, H., Ersahin, M.E., Erdem, S., Atay, B., Kose, B., Kaya, R., Altinbas, M., Sayili, S., Hoshan, P., Atay, D., Eren, E., Kinaci, C., Koyuncu, I., 2013. Effects of the pre-treatment alternatives on the treatment of oil-gas field produced water by nanofiltration and reverse osmosis membranes. Journal of Chemical Technology and Biotechnology 88, 1576-1583.

Pendashteh, A.R., Abdullah, L.C., Fakhru'l-Razi, A., Madaeni, S.S., Abidin, Z.Z., Biak, D.R.A., 2012. Evaluation of membrane bioreactor for hypersaline oily wastewater treatment. Process Safety and Environmental Protection 90, 45-55.

Piemonte, V., Di Paola, L., Prisciandaro, M., 2016. Two phase partitioning bioreactor applied to produced water treatment. Journal of Water Reuse and Desalination 6, 274-279.

Pramanik, B.K., Roddick, F.A., Fan, L., Jeong, S., Vigneswaran, S., 2015. Assessment of biological activated carbon treatment to control membrane fouling in reverse osmosis of secondary effluent for reuse in irrigation. Desalination 364, 90-95.

Qing, Q., Wyman, C.E., 2011. Hydrolysis of different chain length xylooliogmers by cellulase and hemicellulase. Bioresource Technology 102, 1359-1366. 
Rahchamani, J., Mousavi, H.Z., Behzad, M., 2011. Adsorption of methyl violet from aqueous solution by polyacrylamide as an adsorbent: Isotherm and kinetic studies. Desalination 267, 256260.

Ranck, J.M., Bowman, R.S., Weeber, J.L., Katz, L.E., Sullivan, E.J., 2005. BTEX removal from produced water using surfactant-modified zeolite. Journal of Environmental Engineering-ASCE $131,434-442$.

Sarkar, B., Megharaj, M., Xi, Y.F., Krishnamurti, G.S.R., Naidu, R., 2010. Sorption of quaternary ammonium compounds in soils: Implications to the soil microbial activities. Journal of Hazardous Materials 184, 448-456.

Shaffer, D.L., Chavez, L.H.A., Ben-Sasson, M., Castrillon, S.R.V., Yip, N.Y., Elimelech, M., 2013. Desalination and Reuse of High-Salinity Shale Gas Produced Water: Drivers, Technologies, and Future Directions. Environmental Science \& Technology 47, 9569-9583.

Shahmansouri, A., Bellona, C., 2013. Application of quantitative structure-property relationships (QSPRs) to predict the rejection of organic solutes by nanofiltration. Separation and Purification Technology 118, 627-638.

Shanmuganathan, S., Vigneswaran, S., Nguyen, T.V., Loganathan, P., Kandasamy, J., 2015. Use of nanofiltration and reverse osmosis in reclaiming micro-filtered biologically treated sewage effluent for irrigation. Desalination 364, 119-125.

Sillanpaa, M.E.T., Kurniawan, T.A., Lo, W.H., 2011. Degradation of chelating agents in aqueous solution using advanced oxidation process (AOP). Chemosphere 83, 1443-1460.

Singh, P., Quraishi, M.A., Ebenso, E.E., 2014. Thiourea-formaldehyde polymer a new and effective corrosion inhibitor for mild steel in hydrochloric acid solution. International Journal of Electrochemical Science 9, 4900-4912.

Singh, R.P., Tripathy, T., Karmakar, G.P., Rath, S.K., Karmakar, N.C., Pandey, S.R., Kannan, K., Jain, S.K., Lan, N.T., 2000. Novel biodegradable flocculants based on polysaccharides. Current Science 78, 798-803.

Srinivasan, A., Viraraghavan, T., 2008. Removal of oil by walnut shell media. Bioresource Technology 99, 8217-8220. 
Stringfellow, W.T., Cooley, H., Varadharajan, C., Heberger, M., Reagan, M., Domen, J.K., Sandelin, W., Camarillo, M.K., Jordan, P., Donnelly, K., Nicklisch, S., Hamdoun, A., Houseworth, J., 2015. Chapter 2: Impacts of Well Stimulation on Water Resources, An Independent Scientific Assessment of Well Stimulation in California, Volume II: Generic and Potential Environmental Impacts of Well Stimulation Treatments. California Council on Science and Technology, Sacramento, CA.

Stringfellow, W.T., Domen, J.K., Camarillo, M.K., Sandelin, W.L., Borglin, S., 2014. Physical, chemical, and biological characteristics of compounds used in hydraulic fracturing. Journal of Hazardous Materials 275, 37-54.

Strong, L.C., Gould, T., Kasinkas, L., Sadowsky, M.J., Aksan, A., Wackett, L.P., 2014. Biodegradation in waters from hydraulic fracturing: Chemistry, microbiology, and engineering. Journal of Environmental Engineering 140.

Struijs, J., Vandenberg, R., 1995. Standardized biodegradability tests - Extrapolation to aerobic environments. Water Research 29, 255-262.

Sykora, V., Pitter, P., Bittnerova, I., Lederer, T., 2001. Biodegradability of ethylenediaminebased complexing agents. Water Research 35, 2010-2016.

Tchobanoglous, G., Stensel, H.D., Tsuchihashi, R., Burton, F., 2013. Wastewater Engineering: Treatment and Resource Recovery, 5th Edition. Metcalf \& Eddy/AECOM. McGraw Hill Education, New York, NY.

Tezel, U., Tandukar, M., Martinez, R.J., Sobecky, P.A., Pavlostathis, S.G., 2012. Aerobic biotransformation of n-tetradecylbenzyldimethylammonium chloride by an enriched Pseudomonas spp. community. Environmental Science \& Technology 46, 8714-8722.

Thacker, J.B., Carlton, D.D., Hildenbrand, Z.L., Kadjo, A.F., Schug, K.A., 2015. Chemical analysis of wastewater from unconventional drilling operations. Water 7, 1568-1579.

Thiel, G.P., Tow, E.W., Banchik, L.D., Chung, H.W., Lienhard, J.H., 2015. Energy consumption in desalinating produced water from shale oil and gas extraction. Desalination 366, 94-112.

Thoma, G.J., Bowen, M.L., Hollensworth, D., 1999. Dissolved air precipitation solvent sublation for oil-field produced water treatment. Separation and Purification Technology 16, 101-107. 
Tomei, M.C., Annesini, M.C., Daugulis, A.J., 2012. 2,4-Dichlorophenol removal in a solidliquid two phase partitioning bioreactor (TPPB): kinetics of absorption, desorption and biodegradation. New Biotechnology 30, 44-50.

U.S. EPA, 1989. Treatability Potential for EPA Listed Hazardous Wastes in Soil. EPA-600/2-89011. U.S. Environmental Protection Agency, Washington, D.C.

U.S. EPA, 2012. Chapter 5: Estimating Physical / Chemical and Environmental Fate Properties with EPI Suite, TM, Sustainable Futures / P2 Framework Manual 2012. EPA-748-B12-001, Washington, D.C.

U.S. EPA, 2015a. Analysis of Hydraulic Fracturing Fluid Data from the FracFocus Chemical Disclosure Registry 1.0: Data Management and Quality Assessment Report. EPA/601/R-14/006. . U.S. Environmental Protection Agency, Washington, D.C.

U.S. EPA, 2015b. Assessment of the Potential Impacts of Hydraulic Fracturing for Oil and Gas on Drinking Water Resources (External Review Draft). EPA/600/R-15/047. U.S. Environmental Protection Agency, Washington, D.C.

Van der Bruggen, B., Schaep, J., Wilms, D., Vandecasteele, C., 1999. Influence of molecular size, polarity and charge on the retention of organic molecules by nanofiltration. Journal of Membrane Science 156, 29-41.

Veil, J., 2015. U.S. Produced Water Volumes and Management Practices in 2012. Ground Water Protection Council, Inc., Oklahoma City, OK, p. 119.

Walsh, J.M., 2013. Water Management for Hydraulic Fracturing in Unconventional Resources-Part 3: Water Treatment Technologies: Coagulation/Flocculation and Electrocoagulation. Oil and Gas Facilities 2, 10-15.

Watts, R.J., 1998. Hazardous Wastes: Sources, Pathways, Receptors. John Wiley \& Sons, Inc., New York, NY.

Xiao, Y.Y., Roberts, D.J., 2010. A review of anaerobic treatment of saline wastewater. Environmental Technology 31, 1025-1043.

Xu, P., Drewes, J.E., 2006. Viability of nanofiltration and ultra-low pressure reverse osmosis membranes for multi-beneficial use of methane produced water. Separation and Purification Technology 52, 67-76. 
Xu, P., Drewes, J.E., Heil, D., 2008. Beneficial use of co-produced water through membrane treatment: technical-economic assessment. Desalination 225, 139-155.

Xu, P., Drewes, J.E., Kim, T.U., Bellona, C., Amy, G., 2006. Effect of membrane fouling on transport of organic contaminants in NF/RO membrane applications. Journal of Membrane Science 279, 165-175.

Xu, Y., Jiang, J.-Q., 2008. Technologies for boron removal. Industrial \& Engineering Chemistry Research 47, 16-24. 
Table 1. Suitability of candidate treatment technologies for removing classes of hydraulic fracturing additives used in California based on molecular weight, octanol-water partition coefficient $\left(K_{o w}\right)$, soil organic carbon-water partitioning coefficient $\left(K_{o c}\right)$, Henry's Law constant $\left(K_{H}\right)$, and biodegradability.

\begin{tabular}{|c|c|c|c|c|c|c|c|c|}
\hline \multirow[b]{2}{*}{ Chemical function } & \multirow[b]{2}{*}{$\begin{array}{l}\text { Number of } \\
\text { Chemicals }\end{array}$} & \multirow[b]{2}{*}{ Inorganic } & \multicolumn{6}{|c|}{ Number of chemicals appropriate for each treatment technology ${ }^{a}$} \\
\hline & & & RO & NF & Adsorption & $\begin{array}{c}\text { Organic } \\
\text { adsorption }\end{array}$ & $\begin{array}{c}\text { Dissolved air } \\
\text { flotation }\end{array}$ & $\begin{array}{l}\text { Biological } \\
\text { treatment }\end{array}$ \\
\hline Acids and Bases & 23 & $61 \%$ & $11 / 23(0)$ & $1 / 23(0)$ & $1 / 23(0)$ & $1 / 23(0)$ & $2 / 18(5)$ & $9 / 23(0)$ \\
\hline Amine/Amide & 11 & $0 \%$ & $6 / 10(1)$ & $1 / 10(1)$ & $2 / 10(1)$ & $2 / 10(1)$ & $1 / 10(1)$ & $6 / 7(4)$ \\
\hline Biocide & 9 & $0 \%$ & $7 / 9(0)$ & $2 / 9(0)$ & $0 / 8(1)$ & $0 / 8(1)$ & $0 / 8(1)$ & $0 / 9(0)$ \\
\hline Breaker & 7 & $57 \%$ & $2 / 4(3)$ & $0 / 4(3)$ & $0 / 3(4)$ & $0 / 3(4)$ & $0 / 2(5)$ & $3 / 7(0)$ \\
\hline Carbohydrate & 2 & $0 \%$ & $2 / 2(0)$ & $2 / 2(0)$ & $0 / 1(1)$ & $0 / 1(1)$ & $0 / 1(1)$ & $2 / 2(0)$ \\
\hline Clay Control & 4 & $40 \%$ & $3 / 4(1)$ & $1 / 4(1)$ & $0 / 4(1)$ & $0 / 4(1)$ & $0 / 4(1)$ & $1 / 3(2)$ \\
\hline Corrosion Inhibitor & 5 & $0 \%$ & $1 / 2(3)$ & $0 / 2(3)$ & $0 / 1(4)$ & $0 / 1(4)$ & $0 / 1(4)$ & $1 / 1(4)$ \\
\hline Crosslinker & 12 & $67 \%$ & $8 / 11(1)$ & $2 / 11(1)$ & $1 / 6(6)$ & $0 / 6(6)$ & $0 / 2(10)$ & $2 / 10(2)$ \\
\hline Diverting Agent & 1 & $0 \%$ & $0 / 0(1)$ & $0 / 0(1)$ & $0 / 0(1)$ & $0 / 0(1)$ & $0 / 0(1)$ & $1 / 1(0)$ \\
\hline Gelling Agent & 1 & $0 \%$ & $0 / 0(1)$ & $0 / 0(1)$ & $0 / 0(1)$ & $0 / 0(1)$ & $0 / 0(1)$ & $1 / 1(0)$ \\
\hline Iron Control & 3 & $0 \%$ & $2 / 3(0)$ & $0 / 3(0)$ & $0 / 3(0)$ & $0 / 3(0)$ & $0 / 3(0)$ & $3 / 3(0)$ \\
\hline Iron Control, Corrosion Inhibitor & 1 & $0 \%$ & $0 / 1(0)$ & $0 / 1(0)$ & $0 / 1(0)$ & $0 / 1(0)$ & $0 / 1(0)$ & $1 / 1(0)$ \\
\hline $\begin{array}{l}\text { Iron Control, Scale Inhibitor, } \\
\text { Corrosion Inhibitor }\end{array}$ & 4 & $0 \%$ & $4 / 4(0)$ & $3 / 4(0)$ & $0 / 4(0)$ & $0 / 4(0)$ & $0 / 4(0)$ & $3 / 4(0)$ \\
\hline Nutrient Mixtures & 2 & $0 \%$ & $0 / 0(2)$ & $0 / 0(2)$ & $0 / 0(2)$ & $0 / 0(2)$ & $0 / 0(2)$ & $2 / 2(0)$ \\
\hline Polymer & 1 & $0 \%$ & $0 / 0(1)$ & $0 / 0(1)$ & $0 / 0(1)$ & $0 / 0(1)$ & $0 / 0(1)$ & $0 / 0(1)$ \\
\hline QAC & 9 & $0 \%$ & $2 / 2(7)$ & $0 / 2(7)$ & $3 / 4(5)$ & $3 / 4(5)$ & $0 / 4(5)$ & $1 / 2(7)$ \\
\hline Reducing Agent & 3 & $67 \%$ & $2 / 3(0)$ & $0 / 3(0)$ & $0 / 3(0)$ & $0 / 3(0)$ & $0 / 0(3)$ & $1 / 3(0)$ \\
\hline Resin & 3 & $0 \%$ & $2 / 2(1)$ & $0 / 2(1)$ & $0 / 1(2)$ & $0 / 1(2)$ & $0 / 1(2)$ & $0 / 0(3)$ \\
\hline Salt & 6 & $100 \%$ & $3 / 6(0)$ & $0 / 6(0)$ & $0 / 6(0)$ & $0 / 6(0)$ & $1 / 4(2)$ & $0 / 6(0)$ \\
\hline Scale Inhibitor & 9 & $22 \%$ & $2 / 4(5)$ & $2 / 4(5)$ & $0 / 3(6)$ & $0 / 3(6)$ & $0 / 3(6)$ & $1 / 4(5)$ \\
\hline Solvent & 30 & $0 \%$ & $14 / 23(7)$ & $0 / 23(7)$ & $15 / 28(2)$ & $6 / 28(2)$ & $11 / 28(2)$ & $22 / 28(2)$ \\
\hline Surfactant & 45 & $0 \%$ & $11 / 11(34)$ & $6 / 11(34)$ & $25 / 37(8)$ & $20 / 37(8)$ & $8 / 35(10)$ & $31 / 32(13)$ \\
\hline Unknown & 1 & $0 \%$ & $1 / 1(0)$ & $0 / 1(0)$ & $1 / 1(0)$ & $0 / 1(0)$ & $1 / 1(0)$ & $1 / 1(0)$ \\
\hline
\end{tabular}

Tables page 1 
${ }^{a}$ The first number is the number of chemicals appropriate for removal, second number is the total number of chemicals in that chemical category with data, and the number in parentheses is the number of chemicals in that chemical category for which data could not be located. Light shaded cells indicate that less than half of chemicals with data are suited for removal by that treatment technology and dark-shaded cells indicate more than half of chemicals with data are suited for removal by that technology. 
Table 2. Biocide used for hydraulic fracturing in California. ${ }^{a}$

\begin{tabular}{lcc}
\hline \multicolumn{1}{c}{ Chemical name } & CASRN & $\begin{array}{c}\text { Prevalence } \\
\text { of use }\end{array}$ \\
\hline 2-Methyl-3(2H)-isothiazolone & $2682-20-4$ & $73.1 \%$ \\
\hline 5-Chloro-2-methyl-3(2H)-isothiazolone & $26172-55-4$ & $73.0 \%$ \\
\hline Tetrakis hydroxymethyl-phosphonium sulfate & $55566-30-8$ & $7.8 \%$ \\
\hline Ampicillin & $69-53-4$ & $6.5 \%$ \\
\hline Glutaraldehyde & $111-30-8$ & $5.8 \%$ \\
\hline DBNPA (2,2-dibromo-3-nitrilopropionamide) & $10222-01-2$ & $5.4 \%$ \\
\hline MBNPA (2-bromo-3-nitrilopropionamide) & $1113-55-9$ & $5.4 \%$ \\
\hline Formaldehyde & $50-00-0$ & $1.4 \%$ \\
\hline Ethaneperoxoic acid & $79-21-0$ & $0.1 \%$ \\
\hline $\begin{array}{l}\text { a Based on FracFocus v 1/2 data from January 30, 2011 to May 19, 2014 . The list only contains } \\
\text { chemical additives with CASRN. }\end{array}$
\end{tabular}

Tables page 3 
Table 3. Quaternary ammonium compounds (QACs) used for hydraulic fracturing in California. ${ }^{a}$

\begin{tabular}{|c|c|c|}
\hline Chemical name & CASRN & $\begin{array}{l}\text { Prevalence } \\
\text { of use }\end{array}$ \\
\hline $\begin{array}{l}\text { Quaternary ammonium compounds, } \\
\text { bis(hydrogenated tallow alkyl)dimethyl, salts with } \\
\text { bentonite }\end{array}$ & $68953-58-2$ & $6.8 \%$ \\
\hline Dicoco dimethyl ammonium chloride & $61789-77-3$ & $5.1 \%$ \\
\hline $\begin{array}{l}\text { Quaternary ammonium compounds, } \\
\text { benzyl(hydrogenated tallow alkyl)dimethyl, } \\
\text { stearates, salts with bentonite }\end{array}$ & $121888-68-4$ & $3.3 \%$ \\
\hline $\begin{array}{l}\text { Quaternary ammonium compounds, benzyl-C10- } \\
\text { 16alkyldimethyl, chlorides }\end{array}$ & $68989-00-4$ & $3.1 \%$ \\
\hline Decyldimethylamine & $1120-24-7$ & $2.4 \%$ \\
\hline Choline chloride $^{\mathrm{b}}$ & $67-48-1$ & $1.8 \%$ \\
\hline Alkyl dimethylbenzyl ammonium chloride & 68424-85-1 & $0.7 \%$ \\
\hline $\begin{array}{l}\text { Quaternary ammonium chloride, benzylcoco } \\
\text { alkyldimethyl, chlorides }\end{array}$ & $61789-71-7$ & $0.7 \%$ \\
\hline Tetramethyl ammonium chloride & $75-57-0$ & $0.4 \%$ \\
\hline Polyquaternium 15 & $35429-19-7$ & $0.1 \%$ \\
\hline
\end{tabular}




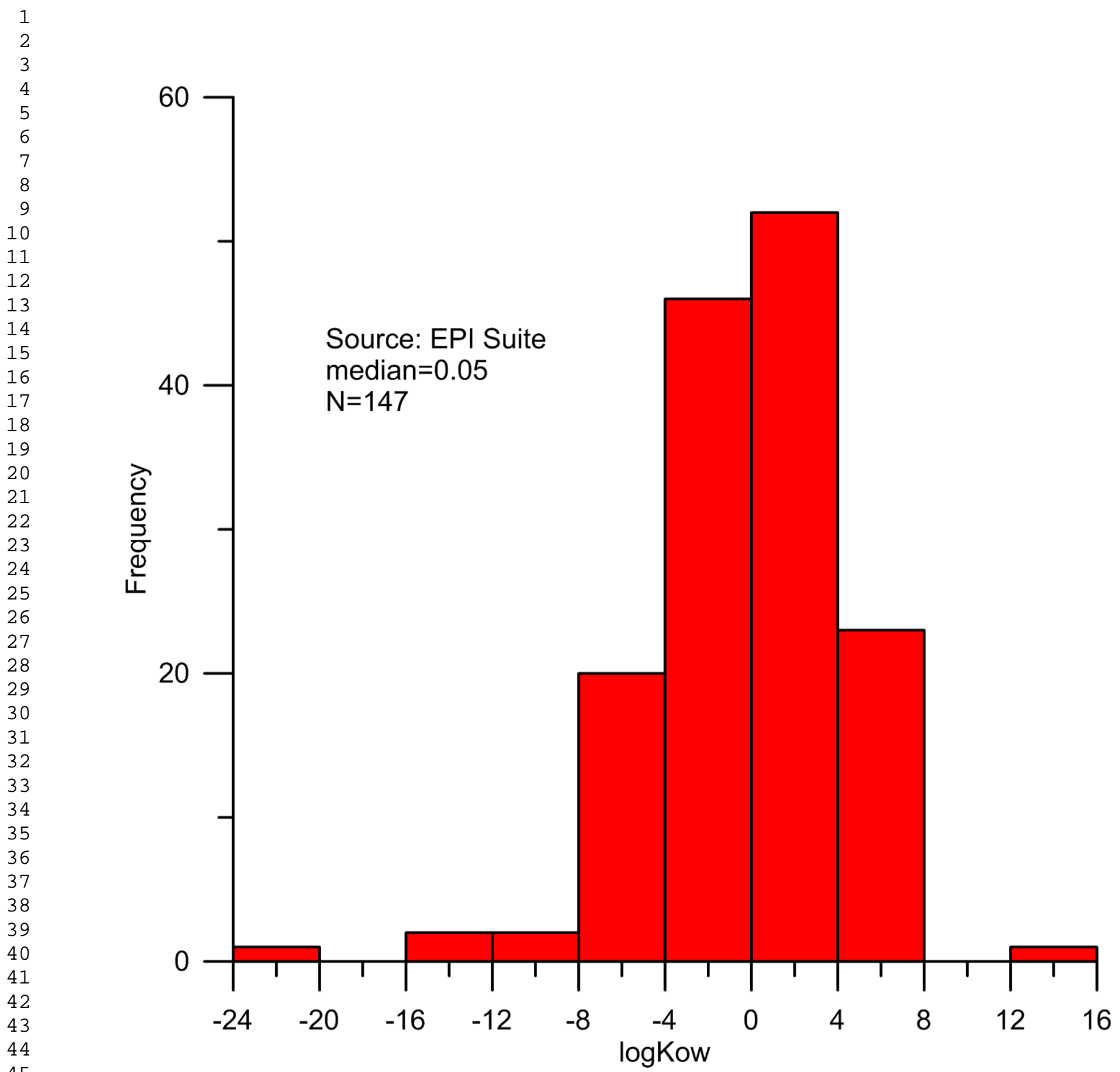

Figure 1. Distribution of octanol-water partition coefficient $\left(K_{o w}\right)$ values for chemicals used in hydraulic fracturing. 


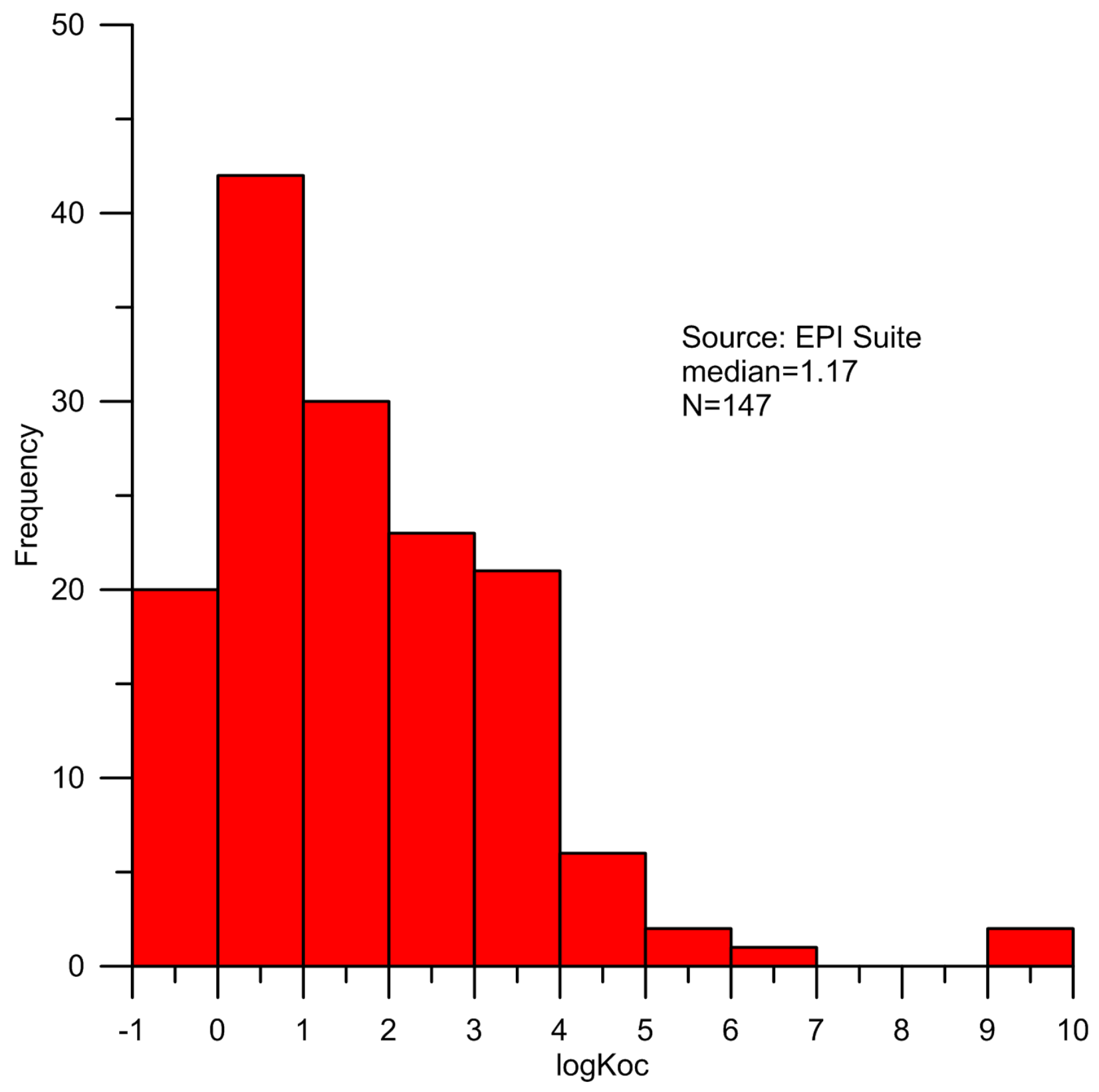

Figure 2. Distribution of soil organic carbon-water partition coefficient $\left(K_{o c}\right)$ values for chemicals used in hydraulic fracturing.

Figures page 2 


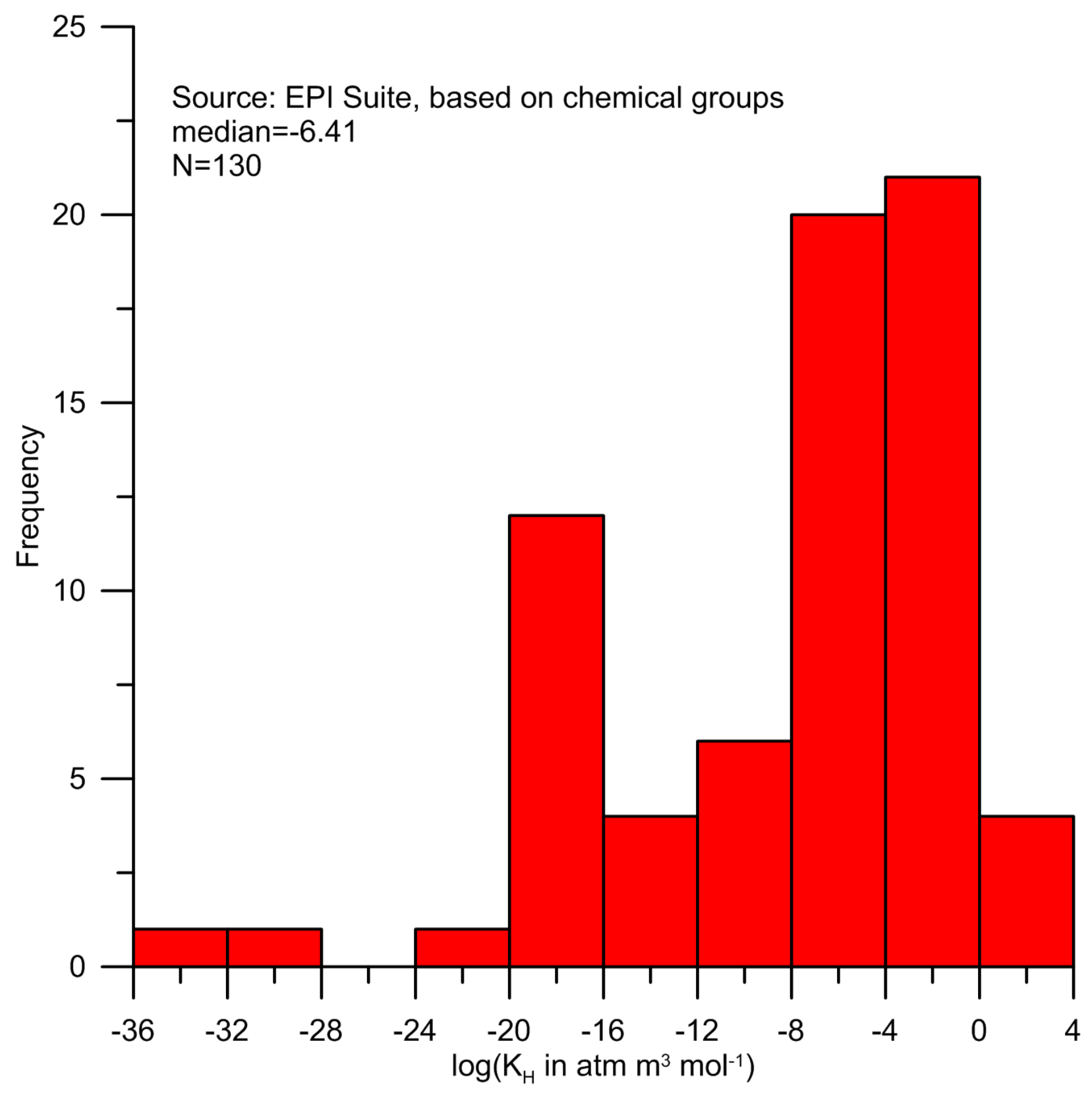

Figure 3. Distribution of Henry's Law constant $\left(K_{H}\right)$ values for chemicals used in hydraulic fracturing. 

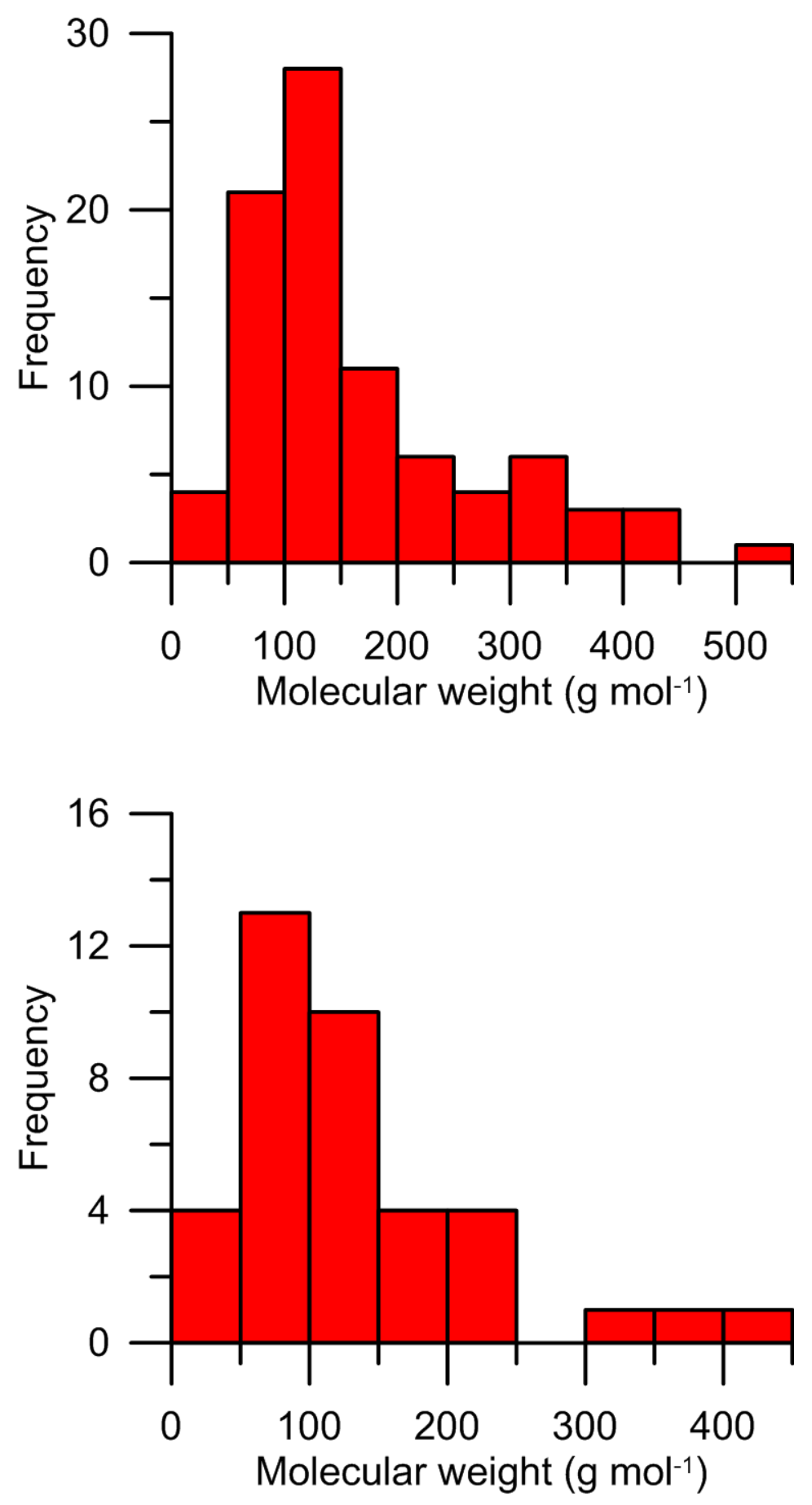

Figure 4. Distribution of molecular weight values for: a) organic compounds, and b) inorganic compounds, used in hydraulic fracturing.

Figures page 4 


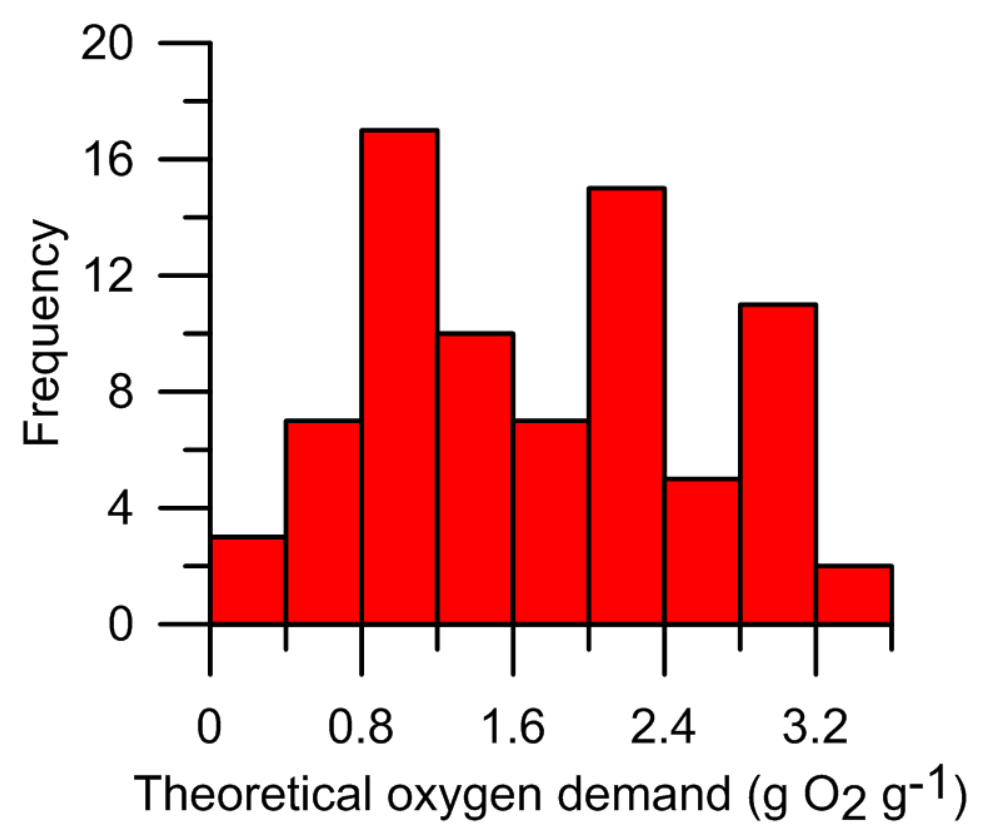

Figure 5. Distribution of theoretical oxygen demand for chemicals used in hydraulic fracturing.

Figures page 5 


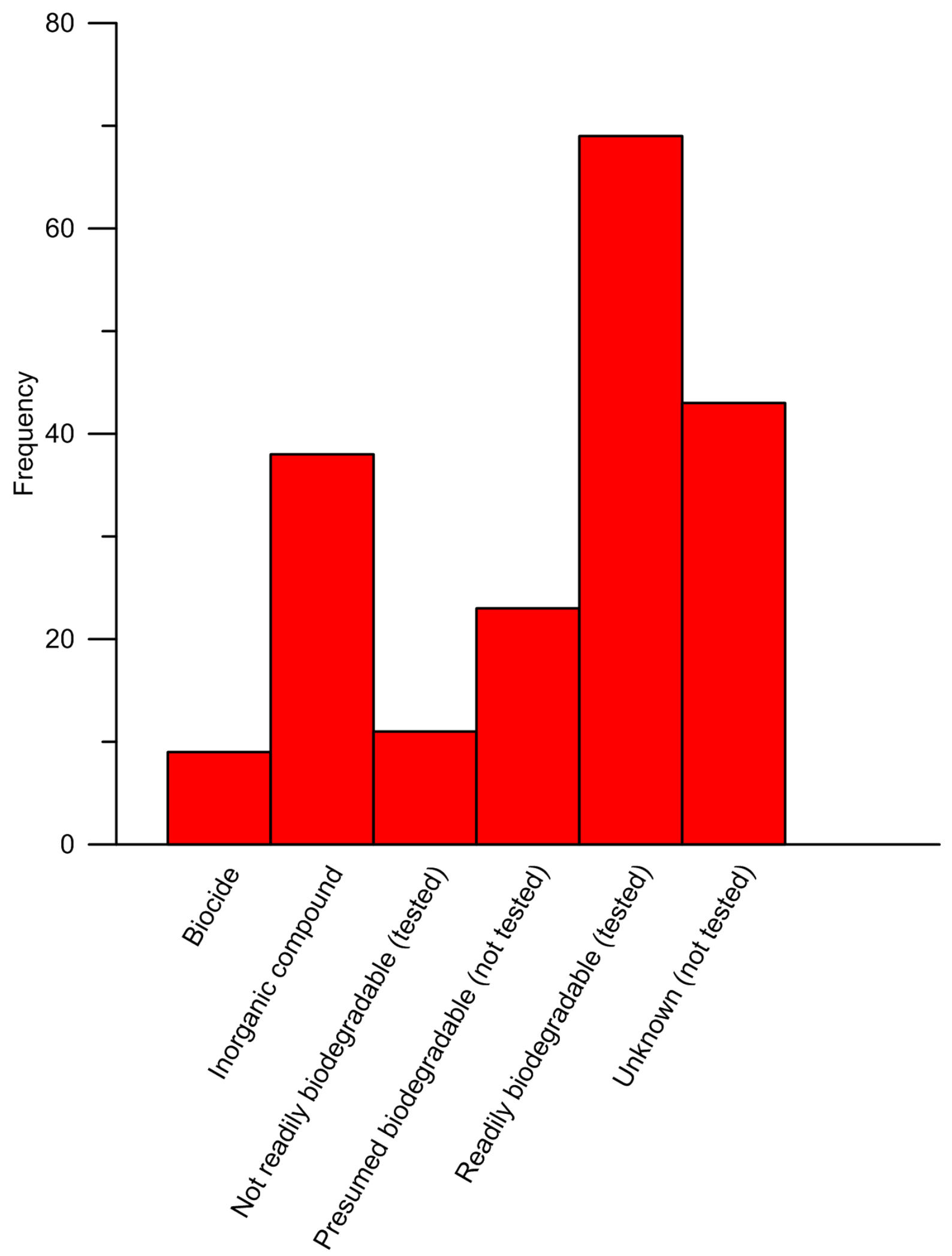

Figure 6. Distribution of biodegradability values for chemicals used in hydraulic fracturing.

Figures page 6 


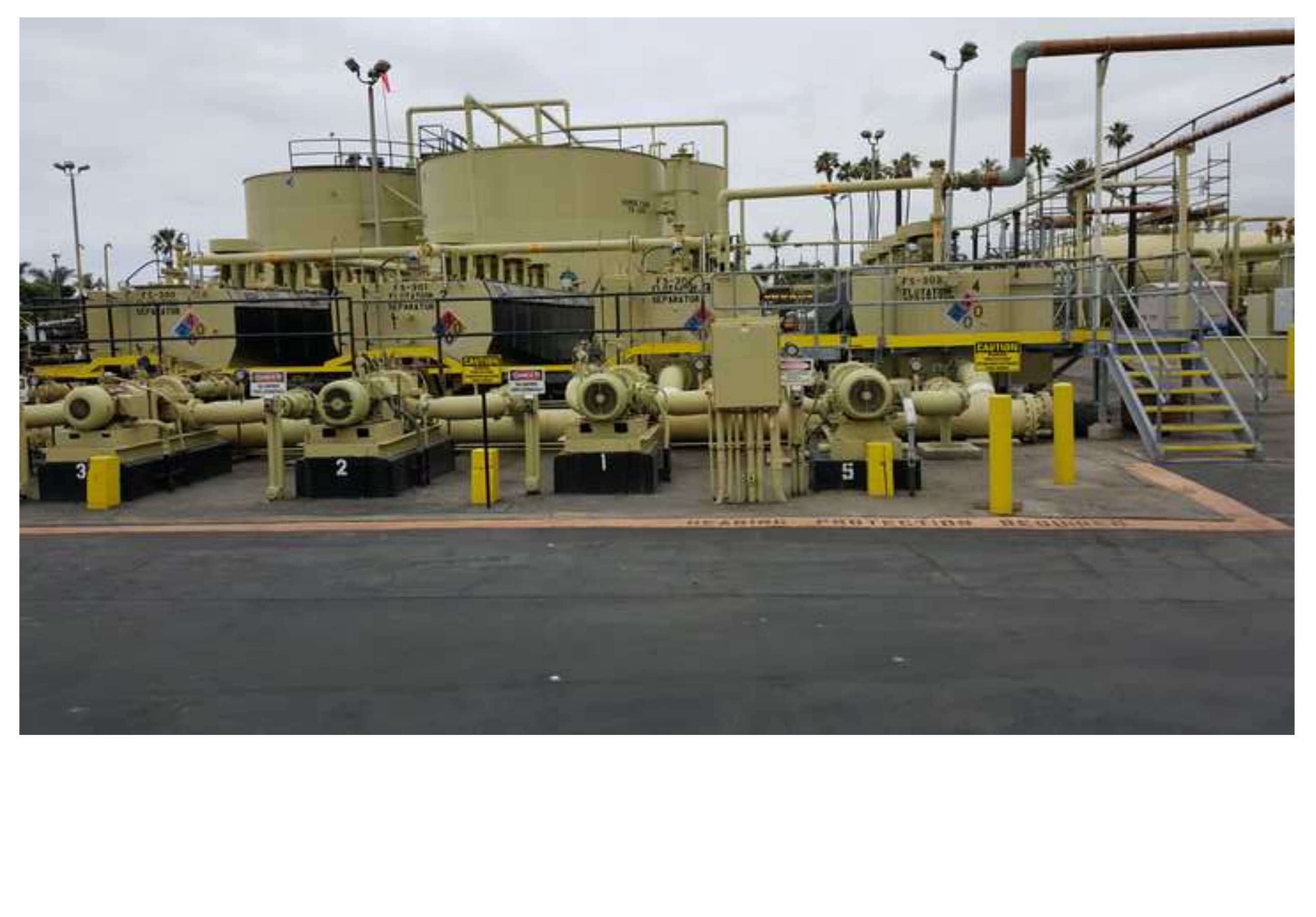

